\title{
Immunotherapy-responsive dorsal column myelopathy in a patient with asymptomatic celiac disease
}

Michael J. Bradshaw, MD, Golnaz Yadollahikhales, MD, and Nagagopal Venna, MD

Neurol Neuroimmunol Neuroinflamm 2018;5:e487. doi:10.1212/NXI.0000000000000487

\author{
Correspondence \\ Dr. Bradshaw \\ Bradshaw.michaelj@gmail.com
}

\section{Case report}

A 64-year-old, left-handed woman with recently diagnosed Hashimoto thyroiditis (treated with levothyroxine) and osteoporosis presented with 3 months of burning sensation in the feet that progressed over several weeks to decreased sensation up the trunk and then to both hands. There was no antecedent trauma or illness. Her father had celiac disease. She worked in retail, ate a normal diet, and did not drink alcohol or smoke. She denied sicca symptoms.

Neurologic examination demonstrated impaired light touch sensation on the lower extremities and trunk to T4 and on the dorsal/palmar surfaces of the hands. Vibration sense was absent in the lower extremities including the iliac crests, and proprioception was decreased in the toes. Temperature sensation was normal throughout. Romberg sign was present, and she had a mildly ataxic gait. The remaining general and neurologic examinations, including reflexes, were normal.

Extensive serum studies including cyanocobalamin/methylmalonic acid, vitamin E, folate, homocysteine, copper, and ceruloplasmin were normal; sedimentation rate, C-reactive protein, serum protein electrophoresis, antinuclear antibodies, Sjögren syndrome antigen A/B, aquaporin $4 \mathrm{IgG}$, rheumatoid factor, and antineutrophil cytoplasmic, serum treponemal, and Borrelia antibodies were normal. CSF was normal including autoimmune/paraneoplastic antibody profile. Brain and spinal cord MRIs were normal. Whole-body PET/CT, mammograms, and pelvic examination were normal. Electromyography and nerve conduction studies were normal. Somatosensory evoked potentials revealed impaired conduction in the large sensory fiber systems at the cervical spinal cord level.

Thyroglobulin antibodies were $>3,000 / \mathrm{mL}(<40 \mathrm{IU} / \mathrm{mL})$, with no thyroid peroxidase antibodies. The tissue transglutaminase immunoglobuilin A (IgA) level was elevated to $48.9 \mathrm{U} / \mathrm{mL}$ $(<4 \mathrm{U} / \mathrm{mL}$ ), as were the gliadin IgA level at $266.4 \mathrm{U} / \mathrm{mL}$ and IgG at $73 \mu / \mathrm{mL}$ (both $<30 \mathrm{U} / \mathrm{mL}$ ) and endomysial IgA 1:80 (normally negative). Esophagogastroduodenoscopy and biopsy were consistent with celiac disease.

She was adhered to a gluten-free diet, and serum celiac serologies normalized; however, her neurologic symptoms continued to progress over a year. Repeat spinal MRI was normal. Given suspicion for an immune-mediated mechanism, she was treated with IV immunoglobulin G (IVIG) $25 \mathrm{~g}$ monthly. She had a remarkable improvement with resolution of widespread sensory loss and dysesthesias. One year after starting IVIG, the gait normalized, Romberg sign resolved, and the only remaining abnormality on was decreased vibration sense in the feet.

From the Partners Multiple Sclerosis Center (M.J.B.), Brigham and Women's Hospital; Massachusetts General Hospital (M.J.B., N.V.), Harvard Medical School, Boston, MA; and University of Illinois (G.Y.), Chicago, IL.

Funding information and disclosures are provided at the end of the article. Full disclosure form information provided by the authors is available with the full text of this article at Neurology.org/NN.

The Article Processing Charge was funded by the authors.

This is an open access article distributed under the terms of the Creative Commons Attribution-NonCommercial-NoDerivatives License 4.0 (CC BY-NC-ND), which permits downloading and sharing the work provided it is properly cited. The work cannot be changed in any way or used commercially without permission from the journal. 
Somatosensory evoked potentials test normalized as well. She remained on monthly IVIG for 2 years before this was tapered. Now, more than 6 years from IVIG initiation, she remains stable.

\section{Discussion}

We present a case of presumed immune-mediated dorsal column-predominant sensory cervicothoracic myelopathy unresponsive to gluten abstinence in a patient with asymptomatic celiac disease. An immune mechanism was suspected, given the history of celiac disease in the father and the detection of celiac disease in the patient by investigation and her known autoimmune thyroiditis; this was strongly supported by the response to IVIG treatment and by the lack of recurrence of the myelopathy in 6 years of follow-up.

Antithyroid antibodies have been associated with myelopathy in a few cases, but not isolated to dorsal column dysfunction, and all had abnormal MRI. ${ }^{1-3}$ Myelopathy manifested only by pure dorsal column sensory loss and with normal appearance of the spinal cord on MRI has not been associated with antithyroid antibodies to our knowledge, and we do not believe that these antibodies were related to our patient's neurologic dysfunction, beyond serving as a nonspecific indicator toward autoimmunity.

Celiac disease is an autoimmune reaction to dietary gluten that is associated with a variety of neurologic abnormalities including peripheral neuropathy, dorsal root ganglionopathy, myopathy, encephalopathy, seizures, and cerebellar ataxia. ${ }^{4}$ Myelopathy is a rare neurologic manifestation that is usually related to nutritional deficiency consequent to celiac disease-related malabsorption, particularly B12 and/or copper deficiency.

Cases of severe progressive neurologic dysfunction have been reported in celiac disease despite a gluten-free diet. ${ }^{5}$ Nearly all had demyelination or degeneration of the dorsal columns on autopsy, changes that would likely be detected on MRI. None were treated with immunotherapy. It is possible that our patient was in the early stages of a similar syndrome, given her progression despite gluten abstinence. Of interest, a small, uncontrolled study of IVIG for ataxia associated with gluten intolerance noted improvement in all patients, supporting a role for immunotherapy in patients with neurologic dysfunction and celiac disease who are not responding to gluten abstinence. ${ }^{6,7}$

Our case illustrates the importance of considering an autoimmune mechanism for subacute myelopathy of unclear etiology even when neuroimaging is normal. It shows diagnostic value of investigating for celiac disease to support an autoimmune mechanism for myelopathy even without symptoms of gluten intolerance. We suggest that in patients with glutenrelated neurologic dysfunction who progress despite gluten abstinence, a trial of immunotherapy is reasonable.

\section{Author contributions}

M.J. Bradshaw: clinical review, manuscript preparation, and literature review. G. Yadollahikhales: manuscript preparation. N. Venna: manuscript preparation and critical review.

\section{Study funding}

No targeted funding reported.

\section{Disclosure}

M.J. Bradshaw serves on the editorial board of Continuum: Lifelong Learning in Neurology. G. Yadollahikhales and $\mathrm{N}$. Venna report no disclosures. Full disclosure form information provided by the authors is available with the full text of this article at Neurology.org/NN.

Received March 13, 2018. Accepted in final form May 3, 2018.

\section{References}

1. Turkoglu R, Tuzun E. Steroid-responsive myeloneuropathy associated with antithyroid antibodies. J Spinal Cord Med 2010;33:278-280.

2. Ishizawa K, Tomioka R, Nakazato Y, Araki N. Isolated myelopathy probably associated with Hashimoto's disease. Neurol India 2012;60:235-236.

3. Azuma T, Uemichi T, Funauchi M, Doi S, Matsubara T. Myelopathy associated with Hashimoto's disease. J Neurol Neurosurg Psychiatry 2000;68:681-682.

4. Hadjivassiliou M, Duker AP, Sanders DS. Gluten-related neurologic dysfunction. Handb Clin Neurol 2014;120:607-619.

5. Kinney HC, Burger PC, Hurwitz BJ, Hijmans JC, Grant JP. Degeneration of the central nervous system associated with celiac disease. J Neurol Sci 1982;53:9-22.

6. Burk K, Melms A, Schulz JB, Dichgans J. Effectiveness of intravenous immunoglobulin therapy in cerebellar ataxia associated with gluten sensitivity. Ann Neurol 2001;50: 827-828.

7. Sander HW, Magda P, Chin RL, et al. Cerebellar ataxia and coeliac disease. Lancet 2003;362:1548. 


\title{
Neurology $^{\odot}$ \\ Neuroimmunology \& Neuroinflammation
}

\author{
Immunotherapy-responsive dorsal column myelopathy in a patient with asymptomatic \\ celiac disease \\ Michael J. Bradshaw, Golnaz Yadollahikhales and Nagagopal Venna \\ Neurol Neuroimmunol Neuroinflamm 2018;5; \\ DOI 10.1212/NXI.0000000000000487
}

This information is current as of August 15, 2018

Updated Information \&

Services

References

Subspecialty Collections

Permissions \& Licensing

Reprints including high resolution figures, can be found at:

http://nn.neurology.org/content/5/5/e487.full.html

This article cites 7 articles, 1 of which you can access for free at: http://nn.neurology.org/content/5/5/e487.full.html\#\#ref-list-1

This article, along with others on similar topics, appears in the following collection(s):

All Spinal Cord

http://nn.neurology.org//cgi/collection/all_spinal_cord

Autoimmune diseases

http://nn.neurology.org//cgi/collection/autoimmune_diseases

Information about reproducing this article in parts (figures,tables) or in its entirety can be found online at:

http://nn.neurology.org/misc/about.xhtml\#permissions

Information about ordering reprints can be found online:

http://nn.neurology.org/misc/addir.xhtml\#reprintsus

Neurol Neuroimmunol Neuroinflamm is an official journal of the American Academy of Neurology.

Published since April 2014, it is an open-access, online-only, continuous publication journal. Copyright

Copyright (C) 2018 The Author(s). Published by Wolters Kluwer Health, Inc. on behalf of the American

Academy of Neurology.. All rights reserved. Online ISSN: 2332-7812.

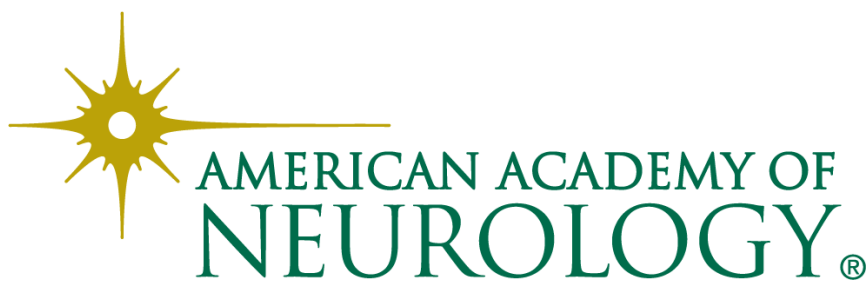

